\title{
Kentleşme Sürecinde Kırsal Alanların Mekansal Değişimi ve Dönüşümü: Denizli Kenti Örneği
}

\author{
Nur Sinem PARTİGÖÇ \\ ${ }^{1}$ Şehir ve Bölge Planlama Bölümü, Pamukkale Üniversitesi, Denizli, Türkiye \\ npartigoc@pau.edu.tr \\ (Geliş/Received:30.10.2017; Kabul/Accepted:14.01.2018) \\ DOI: $10.17671 /$ gazibtd. 347729
}

\begin{abstract}
Özet- "Bütünşehir Yasası" olarak bilinen 6360 sayılı yasa ile büyükşehir belediyelerinin sınırları içerisinde yapılması planlanan nazım ve uygulama imar planları için özellikle kent merkezlerine yakın veya kentlerin gelişme yönlerinde konumlanan kırsal nitelikli yerleşmeler "potansiyel kentsel arsalar" olarak düşünülen alanlardır. Bu çalışmanın amacı, kanunun yürürlüğe girdiği 2012 yılına kadar kırsal niteliği korunan ve tarım arazisi olarak kullanılan alanlara yönelik getirilen kullanım kararlarının kanunun yürürlüğe girmesiyle oluşturduğu mekânsal etkilerin incelenmesidir. Çalışma kapsamında, Denizli İli Pamukkale ve Merkezefendi İlçeleri’nde yer alan ve kanunla tüzel kişiliği ortadan kaldırılarak "mahalle" statüsüne alınan yerleşimler örnek alan olarak seçilmiştir. 2007-2017 yılları arasında çalışma alanı olarak belirlenen alanda kentsel ve kırsal alan kullanımlarında meydana gelen mekansal değişikliklerin incelenmesi ve bu değişikliklerin şehir planlama disiplini açısından incelenmesi hedeflenmektedir. Google Earth yazılımı aracılığıyla elde edilen ve farklı yıllara ilişkin uydu görüntüleri kullanılarak ortaya konulan mekansal değişimlere ilişkin yapılan değerlendirmelerin, kentsel ve mekânsal gelişme dinamiklerinin yönetilmesinde belirleyici olan yerel düzeydeki yönetimsel yapılanmaya ait yetki ve sorumluklarının nasıl ve hangi amaçla kullanıldığını, özellikle tarımsal alanlar üzerindeki mekânsal etkilerini ortaya koyması bakımından oldukça önemli olduğu düşünülmektedir.
\end{abstract}

\section{The Spatial Variation of Rural Settlements in the Urbanization Process: The Case of Denizli City}

\begin{abstract}
The rural settlements, located near urban settlements' centers or in the direction of urban developments, are "potential urban areas" for the master and implementation plans within the boundaries of metropolitan municipalities following the new Law No. 6360. The purpose of the study is to examine the spatial changes which affect distinctly the agricultural lands and rural settlements from the year 2012 which the critical spatial decisions had been applied by local authorities under the influence of the Law No. 6360 known as the "Metropolitan Law". The settlements are disincorporated and their statuses are changed as "neighborhood", are chosen as the case areas in Pamukkale and Merkezefendi districts within the boundaries of Denizli Metropolitan city. The spatial changes occurred in urban and rural settlements in in case areas between the years 2007 - 2017 are analyzed comparatively and also the results of spatial changes are evaluated in terms of city planning discipline. It is quite apparent that these evaluations based on the satellite images of case areas obtained using Google Earth software for different years have a critical role to reveal the spatial effects on agricultural lands and rural settlements as the consequences of local applications based on the authorities and responsibilities of metropolitan municipality that are decisive in terms of the spatial and urban development dynamics.
\end{abstract}

Keywords - Rural settlements, Urban development dynamics, Metropolitan Law, Urban planning, Denizli city.

\section{GİRIŞ (INTRODUCTION)}

Dünyada yaşanan gelişmelere paralel olarak Türkiye'deki yönetimsel yapılanma ve idari biçimlenişte köklü değişimler meydana gelmiştir. Hizlı ve kontrolsüz kentleşme süreçlerinin yol açtığı büyük şehirlerde izlenen üretim - birikim ilişkileri, beraberinde getirdiği göç kavramı, artan nüfusun etkisiyle kentlerin büyümesi 
sonucunda ortaya çıkan yeni yönetimsel sorunlar ve kırkent ikileminin toplumsal yapılanmaya etkilerinin daha belirgin hale gelmesi gibi sorunlarla tek kademeli bir yönetim sistemiyle başa çıkmanın münkün olamayacağ anlaşılmıştır. Bu durum, 1970'li yıllardan başlayarak hem dünyanın hem de Türkiye'nin gündeminde mevcut yönetim sistemini ikame edebilecek yeni yönetim modellerinin araştırılmaya ve tartışılmaya başlanmasının temel gerekçesi olarak gösterilebilir.

1980'li y1llara kadar ülkemizde "metropoliten alan" niteliği taşıyan şehirler için farklı öneriler (belediye birliklerinin kurulması, demokratik belediyecilik, üretici tüketimi düzenleyici belediyecilik, işbirliği ve dayanışmayı temel alan belediyecilik, kaynak yaratıcı belediyecilik, vb.) $[8,10]$ geliştirilmiş, ancak bu öneriler hayata geçirilememiştir. 1980'li yıllara gelindiğinde ise, küreselleşme söyleminin gündeme geldiği, mekansal ve yönetimsel organizasyonda önemli değişimlerin yaşandığ1, yerel yönetimlerin güçlendirilip taşra yönetiminin ön plana çıkarıldığı bir döneme tanıklık edilmiştir. 1984 yılında çıkarılan 3030 sayılı "Büyükşehir Belediyelerinin Yönetimi Hakkında Kanun", büyükşehir belediyelerine geniş imtiyazlar tanıyan ve "özerk bir yerel yönetim" anlayışını ortaya koyan ve büyük şehirlerin yönetimi üzerine kapsamlı reformların ilk aşaması niteliği taşıyan yasal bir düzenlemedir [2, 4] .

$\mathrm{Bu}$ kanunun yürürlüğü girmesiyle, Türkiye'nin ilk büyükşehir belediyeleri İstanbul, İzmir ve Ankara'da kurulmuştur ve bu sayede çok sayıdaki şehrin “büyükşehir statüsü” kazanması yönündeki çabaları ivme kazanmıştır. 1993 yılında çıkarılan 504 sayılı Kanun Hükmünde Kararname ile büyükşehirlerin kurulması ve sayılarının arttırılmasının yolu açılmıştır. İçlerinde Adana, Bursa, Konya, Antalya, Diyarbakır, Eskişehir, Erzurum gibi şehirlerin bulunduğu büyükşehirlerin sayısı 2000'li yıllara gelindiğinde toplam 16'ya yükselmiştir [18].

Büyükşehirlerin yönetimi üzerine gerçekleştirilen ikinci büyük reform olarak nitelendirilen 2004 yılında 5216 say1lı "Büyükşehir Belediyesi Kanunu", yerel yönetimlerin etkinliğinin arttırıldığı ve dünyanın çeşitli coğrafyalarında küreselleşme sürecinde yaşanan değişimlere ayak uydurulduğu bir süreçte gündeme gelmiştir. Büyükşehir belediyesi sınırlarına hem ölçek hem de nüfus kriterinin getirildiği bu kanunun yürürlüğe girmesiyle, 3030 sayılı kanun yürürlükten kaldırılmış, yerel yönetimlerin hizmet alanını genişletecek büyükşehirlere yönelik yeni bir sistem getirilmeye çalışılmıştır. "Pergel Yasası" olarak bilinen ve sınır genişletmesi esasına dayanan bu kanunla, bir yerleşim yerinde büyükşehir kurulabilmesi için o yerleşime (belediye sınırları baz alınarak) ve çevresindeki yerleşim yerlerine (en fazla $1 \mathrm{~km}$ uzaklıkta yer alan) ait nüfusun toplam 750.000 kişi olması şartı getirilmiştir.

Yerleşim yerlerinin sınırlarının genişletilmesi konusunda şehir bazında farklılaşmalar görülmektedir. İstanbul (2012 y1l itibariyle il nüfusu 13.854.740 kişi) ve Kocaeli (2012 yılı itibariyle il nüfusu 1.634.691 kişi) şehirlerinde büyükşehir sınırları (mülki sınırlar) il sınırlarına genişletilirken; Ankara (2012 yılı itibariyle il nüfusu 4.965 .542 kişi) ve İzmir (2012 yılı itibariyle il nüfusu 4.005.459 kişi) şehirlerinde azami 50 km'lik çapta kalan tüm yerleşimler büyükşehir belediyelerinin yetki ve sorumluluk sahasında kalacak biçimde düzenlemeler yapılmıştır. Adana ve Bursa'da büyükşehir belediyelerinin sorumluluk sahaları azami $30 \mathrm{~km}$ 'lik çapta alana genişletilirken; Eskişehir, Gaziantep, Kayseri, Sakarya, Diyarbakır, Konya, Mersin, Antalya, Erzurum ve Samsun kentlerinde ise büyükşehir belediyelerinin sorumluluk sahalarının azami $20 \mathrm{~km}$ 'lik çapta alana genişetilmiştir [2].

Yerel yönetimlere yönelik son reform ise 5747 sayılı "Büyükşehir Belediyesi Sınırları İçerisinde İlçe Kurulması ve Bazı Kanunlarda Değişiklik Yapılması Hakkında Kanun" ve 2012 yılında çıkarılan 6360 sayılı “On Dört İlde Büyükşehir Belediyesi ve Yirmi Yedi İlçe Kurulması ile Bazı Kanun ve Kanun Hükmünde Kararnamelerde Değişiklik Yapılmasına Dair Kanun"un yürürlüğe girmesidir. 5747 sayılı kanunun yürürlüğe girmesiyle, nüfusu 2000 kişinin altında kalan belediyeler ile ilk kademe belediyelerinin kapatılması gündeme gelmiştir.

Yeni yönetim modeli olarak ortaya konulan ve 6360 sayılı "Bütünşehir Yasası" olarak bilinen bu kanun kapsamında uygulanan "büyükşehir modeli”, büyükşehir belediyesi sayısının ülke genelinde 30'a yükseltilmesini, büyükşehir statüsündeki illerde il özel idarelerinin varlığına son verilmesini, yaklaşı 18.000 belde ve köyün tüzel kişiliğinin kaldırılmasını, köylerin ve beldelerin mahalle statüsüne alınmasını, yeni ilçe ve belediyelerin oluşturulmasını, büyükşehir statüsü verilen şehirlerde Yatırım İzleme ve Koordinasyon Başkanlıkları kurulmasını ve bütün büyükşehirlerde il sınırlarının belediye sınırı olmasını ifade etmektedir [18]. Şekil 1'de 6360 sayılı kanun öncesinde ve sonrasında ülke genelinde büyükşehirlerin mekansal dağılımı verilirken; Tablo 1'de ise 6360 sayılı kanun öncesinde ve sonrasında değişen belediye sayıları sunulmuştur.

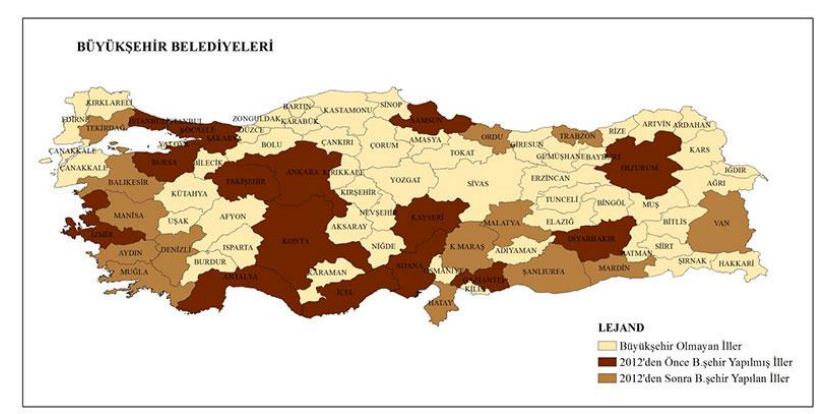

Şekil 1. 6360 Sayılı Kanun Öncesinde ve Sonrasında Büyükşehirler 
Tablo 1. 6360 Sayilı Kanun Öncesinde ve Sonrasinda Değişen Belediye Sayıları [2]

\begin{tabular}{|l|c|c|}
\hline Yerel Yönetimler & $\begin{array}{c}\text { 6360 Sayılı } \\
\text { Kanun } \\
\text { Oncesinde } \\
\text { Belediye } \\
\text { Sayıları }\end{array}$ & $\begin{array}{c}\text { 6360 Sayılı } \\
\text { Kanun } \\
\text { Sonrasında } \\
\text { Belediye } \\
\text { Sayıları }\end{array}$ \\
\hline Büyükşehir belediyesi & 16 & 30 \\
\hline Büyükşehir ilçe belediyesi & 143 & 501 \\
\hline İl belediyesi & 65 & 51 \\
\hline İlçe belediyesi & 749 & 416 \\
\hline Belde belediyesi & 1977 & 395 \\
\hline Belediye sayısı (Toplam) & 2950 & 1392 \\
\hline İl özel idareleri (Toplam) & 81 & 52 \\
\hline Köy idareleri (Toplam) & 34283 & 17720 \\
\hline
\end{tabular}

$\mathrm{Bu}$ çalışmanın amacı, kanunun yürürlüğe girdiği 2012 yılına kadar kırsal niteliği korunan ve tarım arazisi olarak kullanılan alanlara yönelik getirilen kullanım kararlarının kanunun yürürlüğe girmesiyle oluşturduğu mekânsal etkilerinin incelenmesi ve 2007 - 2017 yılları arasında meydana gelen mekansal değişikliklerin şehir planlama disiplini bakımından değerlendirilmesidir. Çalışma kapsamında, Denizli İli Pamukkale ve Merkezefendi İlçeleri'nde yer alan ve 6360 sayılı kanunla tüzel kişiliğgi ortadan kaldırılarak "mahalle" statüsüne alınan yerleşmeler örnek alan olarak seçilmiştir. Çalışma alanı, Pamukkale İlçesi’nin güneyini ve Merkezefendi İlçesi’ni kapsamaktadır. Bu iki merkez ilçe, hâlihazırda verimli tarım arazileri ve orman alanları bakımından oldukça zengin olmakla birlikte, Denizli kentinin gelişme yönlerinde yer almaları bakımından da artan konut talebine yönelik mekânsal gelişmenin gözlendiği yerleşimlerdir.

İlgili yasanın yürürlüğe girmesinden önceki ve sonraki dönemi kapsayacak biçimde 2007 - 2017 yılları arasında çalışma alanında kentsel ve kırsal alan kullanımlarında meydana gelen mekansal değişikliklerin uydu görüntülerini karşılaştırmalı biçimde incelenmesi ve ve bu değişikliklerin şehir planlama disiplini açısından incelenmesi çalışmanın yöntemini oluşturmaktadır. Yapılan değerlendirmelerin, kentsel ve mekânsal gelişme dinamiklerinin ve eğilimlerinin yönetilmesinde belirleyici olan yerel düzeydeki yönetimsel yapılanmaya ait yetki ve sorumluklarının nasıl ve hangi amaçla kullanıldığını, özellikle tarımsal alanlar üzerindeki mekânsal etkilerini ortaya koyması bakımından oldukça önemli olduğu düşünülmektedir.

\section{6360 SAYILI KANUNUN KENTSEL PLANLAMA ÜZERINNE OLASI ETKİLERİ (POSSIBLE EFFECTS ON URBAN PLANNING OF 6360 LEGISLATIVE)}

6360 sayılı kanun ile meydana gelen değişiklikler, hâlihazırda ülkemizin metropoliten alanların etkin biçimde yönetilmesi konusundaki sınırlı deneyimleri göz önünde bulundurulduğunda, gerek kurumsal-yönetimsel yapılanma gerekse mekansal planlama süreçleri bakımından oldukça önemlidir. $\mathrm{Bu}$ değişiklikler incelendiğinde, Türkiye genelinde kentleşme oranı kritik biçimde artış göstermiş olduğu (\%77'den \%91'e çıkması); 2012 - 2013 yılları arasında kırsal nüfusun yaklaşı 10 milyon kişi azaldığı ve kentsel nüfusun yaklaşık 11 milyon kişi arttı̆̆ı (İrdem ve Mutlu, 2016); ülkedeki nüfus yoğunluğunun $100 \mathrm{kişi} / \mathrm{km}^{2}$ olduğu ve büyükşehir statüsüne getirilen 12 şehrin (Şanlıurfa, Mardin, Balıkesir, Denizli, Kayseri, Kahramanmaraş, Muğla, Malatya, Eskişehir, Van, Konya ve Erzurum) nüfus yoğunluğu bakımından ülke ortalamasının altında kaldığı görülmektedir [9].

Kanunun yürürlüğe girmesi sonucu meydana gelen değișikliklerden biri olarak, belde ve köylerin tüzel kişiliğinin kaldırılması tüm yerleşim birimlerinin niteliksel ve niceliksel bakımlardan "şehir" olarak değerlendirilmesine neden olmuştur. Dolayısıyla, büyükşehir belediyelerinin ölçek ekonomisi baz alınarak "daha az kaynakla daha kaliteli hizmet sunma" [11] tasarısı yerini yerel yönetimlerin yetki ve sorumluluğu altındaki yerleşim birimlerine hizmet sağlaması konusunda haklı endișelere bırakmıștır. Beldelerin kapatılması sonucunda yerel yönetim hizmetlerinin en yakın ilçe merkezinden karşılanacak olması, dağınık halde konumlanan yerleşim yerlerinde ikamet eden vatandaşların mevcut hizmetlere erişiminde ve yerel ölçekteki kararlara katılımda ciddi sorunlar doğurmaktadır. $\mathrm{Bu}$ duruma örnek olarak, Muğla İli Marmaris İlçesi sınırlarında yer alan Bozburun Beldesi verilebilir. İlçe merkezi ile beldenin arasındaki mesafenin yaklaşı $50 \mathrm{~km}$ olduğu düşünülürse, özellikle yaz aylarında turizm potansiyeli bakımından önemli olan bu yerleşimde belediye teşkilatının kapanması ve hizmetlerin daha uzak bir merkezden verilmeye çalıșılması nedeniyle önemli aksamalar yaşanması söz konusudur [14].

Yerleşimlerin yapısal ve karakteristik niteliklerinin korunması (kıra özgü unsurlar, kırsal kimlik, özgün mimari doku, vb.), 6360 sayılı kanunun yürürlüğe girmesiyle farklı meslek alanlarında endişeleri de beraberinde getirmiştir. Ülke genelinde köylerin \%47'sinin tüzel kişiliğinin kaldırılmasının ve "mahalle" statüsüne alınmasının üretim biçimlerinden sosyoekonomik yapıya kadar pek çok değişim ve dönüşümü tetiklemesi, bir başka deyişle "köylerin kentlileştirilmesi" [11] söz konusudur. Bu noktadan hareketle, özellikle kent merkezlerine yakın veya kentlerin gelişme yönlerinde konumlanan kırsal nitelikli yerleşmelerin büyükşehir belediyelerinin sınırları içerisinde yapılan ve yapılması planlanan her ölçekteki nazım ve uygulama imar planları için "potansiyel kentsel arsalar" ve "proje alanı" olarak 
düşünülmesi endişesi gündeme gelmiştir. Bu sürecin doğal bir sonucu olarak, köyde yaşayan halkın kendi bildiği yaşam biçimi üzerindeki haklarını kaybetmesi söz konusudur.

442 sayılı Köy Kanunu'nda "cami, okul, otlak, yaylak, baltalık gibi orta malları bulunan ve toplu veya dağınık evlerde oturan insanlar, bağ, bahçe ve tarlalarıyla birlikte bir köy teşkil ederler" ifadesiyle kırsal nitelikteki alanlar ve bu alanlarda yürütülen tarımsal faaliyetler vurgulanmıştır [16]. Bu kapsamlı tanımın varlığına rağmen, kıra özgü üretim biçimlerinden olan tarım ve hayvacılık faaliyetlerinin yapılabileceği alanların büyükşehirlerde nasıl karşılık bulacağı, 6360 sayılı kanun sonrası muğlaklığını koruyan konulardan biridir. Kanun kapsamında yapılan yasal düzenlemeler ile mahalle statüsüne dönüşen köylerde bu tip kırsal faaliyetlerin engellemeyeceği; aksine modern üretim ve yetiştirme teknikleri, işbirlikleri ve projelerle çiftçilerin destekleneceği ifade edilmektedir [17]. Büyükşsehir belediyelerinin tarımsal altyapısının bulunmaması nedeniyle, köy tüzel kişiliğine ait alanların (meralar, otlaklar, vb.) büyükşehir belediyelerinin mülkiyetine geçmesi ve bu tür alanların kentsel ölçekte yapılması planlanan her tür yatırım için kiralanması / satılması / imara açılması durumunda, tarım ve hayvacılık faaliyetlerinin etkinliğinin azalmasına yol açması öngörülebilir bir sonuçtur. Buna ek olarak, tarımsal sulama birimlerinin (sulama kanalları, göletler, vb.) ve hayvancılık faaliyetlerinin yürütüldüğü birimlerin (depolar, ahırlar, vb.) kısa ve orta vadede "kentsel nitelikli yatırımlardan" etkilenmesi söz konusudur [1].

Kent planlama disiplini çerçevesinde mekanı ve mekansal organizasyonu şekillendiren faktörlerden biri de yasal düzenlemelerin yerleşmeler düzleminde yarattığı / yaratacağı olası sosyo - kültürel sonuçlardır. Yasal bir süreç olarak algılanmak yerine bir sosyalleşme süreci olarak algılanması gereken "kentli olma / kentlilik "bilinci", mahalle haline getirilerek kente eklemlenen kırsal yerleşmelerde yaşayan halk için başlıca sorunlardan biridir. Kentliliğe özgü tutum ve davranışların zaman içerisinde kazanılması ve "birey" olma bilincinin üstüne şekillenen kentlilik kavramı [11], kırsal nitelikli yerleşmelere özgü yapıyla çelişen bazı özelliklere sahiptir. Örneğin kentsel yaşantı içerisinde maddiyatçılığın temel alındığ 1 toplumsal ilişkiler, farklı sektörlerde iş olanaklarına imkan sunulması, işbölümü ve uzmanlaşmanın sağlanması, heterojen nüfus yapısının bulunması, bireyselliğini koruma uğraşı, sorumluluk ve hakların bilincinde olma gibi özellikler gözlemlenirken; kırsal yaşantı içerisinde ekonominin ağırlıklı olarak tarıma dayanması, komşuluk ilişkilerinin ve dayanışmanın daha güçlü olması, homojen bir nüfus yapısının gözlenmesi ve aidiyet duygusunun ağır basması gibi nitelikler öne çıkmaktadır. $\mathrm{Bu}$ karşılaştırma ortaya koymaktadır ki, kısa vadede köyde yaşayan halk zorla kentlileştirmeye uğraşıldığında, değişime maruz kalınan her yerleşimde anomi halinin görülmesi olasıdır.
Geleneksel ve yerleşimin kendine özgü niteliklerini yansıtan mimari dokuların / yapılaşma türlerinin ağırlıklı olarak belde ve köylerde görüldüğü bilinmektedir. Buna örnek olarak İzmir İli Ödemiş İlçesi'nde yer alan Birgi Beldesi verilebilir. Kuruluşunun 1889 yılına dayandığı belde, pek çok medeniyete ev sahipliği yapmış bir yerleşim niteliği taşımakta olup [14]; 6360 sayılı kanunun yürürlüğe girmesiyle tüzel kişiliğine son verilmiştir. Bu müdahale sonucunda, hem yaklaşık 120 yıllık bir yerel yönetim kültürünün ortadan kaldırılmış, hem de yerleşime has doku özelliklerinin korunması ve yaşatılması da riskli hale gelmiştir. Konut ve emlak sektörlerinin "yeni yatırım alanları" olarak değerlendireceği kırsal nitelikli alanlarda uygulanan / uygulanmak istenen projelerin "yörenin geleneksel, kültürel ve mimari özelliklerine uygun tip mimari projeler" olup olmayacağı endişe vericidir. Kentsel alanda günümüz örneklerinin yapısal özellikleri (tek tip yapılaşma, kimliksiz yapı ve sokaklar, vb.) dikkate alındığında, "mimari kültür mirasının" korunması konusunda üretilen strateji ve politikaların kent planlama pratiği temelinde yetersiz kalacağı ortadadır.

Planlama ilkeleri ve pratiğindeki uygulamalar temelinde 6360 sayılı kanunun doğuracağı olası bir diğer sonuç, parçacıl ve planlamada kademeli birliktelik ilkesiyle ters düşen, alt ölçek planlarını hiçe sayan üst ölçek plan kararlarının geliştirildiği bir planlama sürecidir. Kanunun yürürlüğe girmesiyle bir büyükşehirin kapsadığı tüm yerleşmelere ilişkin plan kararlarının üst ölçekli olarak üretilmesi, alt ölçekle eşgüdümlü olmayan, bütünden kopuk ve yerelin dinamiklerini gözetmeyen bir yaklaşım ortaya koymuştur. Tek bir otoritenin yetkisiyle yönetilen ve bütüncül olmayan planlama süreçleri sonunda orta ve uzun vadede mekansal ve toplumsal olarak önemli değişimler gözleneceği ve geri dönüşü olmayan planlama kararları ile yerleşimlerin yüzleşmek durumunda kalacağ ifade edilmektedir [5, 6].

\section{DENIZLI'DE METROPOLITENLEŞME SÜRECI (METROPOLITANIZATION PROCESS IN DENIZLI)}

Denizli, tarih öncesi dönemlerden itibaren konumu nedeniyle önemli bir geçiş bölgesi olan ve Cumhuriyet'in ilanından günümüze kadar geçen süreçte pek çok açıdan değişikliğe uğrayan büyükşehirlerden biridir. Sanayileşme faaliyetlerinin artması, hızlı kentleşme ve nüfusun artması gibi etkenlere bağlı olarak, Denizli kentinin son y1llarda kalkınan şehirlerden biri olduğu bilinmektedir. Tekstil ve metal ağırlıklı sanayi faaliyetlerinin gün geçtikçe artması, tarımsal faaliyetler (sulu tarım, kuru tarım, hayvancılık, ormancılık, vb.), gelişmiş bir tarımsal altyapının varlığı, coğrafi konumu, belirli özellikleri ile öne çıkan büyükşehirlere erişim kolaylığ 1 , İzmir limanı ile ilişkili olarak ticari faaliyetlerin sürdürülmesi, doğal ve kültürel zenginlikleri ile tanınan bir şehir olması gibi faktörler Denizli'nin artan nüfus ve işgücü hareketliliğini açıklamakta olup; kent bu özellikleri ile "kalkınma öncelikli kentler” kapsamına alınmıştır [20].

Şehir, 1950'li yıllarda sanayileşme sürecinde teşvik tedbirleri konusunda ayrıcalıklar elde ederek ekonomik 
açıdan yükselen şehirler arasında yerini alırken; ekonomik alanda elde ettiği başarıyı şehir planlamasına ve mekan organizasyonuna yansıtamamıştır. Yalnızca doğal afetler (özellikle deprem) sonucunda mevcut geleneksel dokuda meydana gelen değişiklikler değil; hızlı ve kontrolsüz kentleşme, hızlı nüfus artışı karşısında şehrin artan barınma ve donatı taleplerini karşılamak konusunda yetersiz kalması, yoğun göç alması ve üretim tesislerinin sayısının ciddi oranda artması gibi nedenlerden dolayı Denizli şehrinin kendisi bir "üretim mekanına" dönüşmüştür. Sanayileşmenin kentsel mekanda yayılarak büyümesi, kentsel boşlukların zaman içerisinde azalmasıyla kentsel rantın kendini göstermesi, nüfus hareketleri ile kentleşme süreci birbirine parallellik sağlayamaması ve kentsel yığılmaların gözlenmesi gibi faktörler özellikle 1990 sonrası dönemde küreselleşmenin etkilerinin hissedildiği Denizli'de fiziksel mekanı ve büyüme eğilimlerini önemli ölçüde şekillendirmiştir [19].

Denizli'de ilk planlama çalışmaları 1960'lı yıllarda yapılmış olup; kentsel gelişme eğilimleri İzmir, Ankara ve Tavas karayollarının bulunduğu güzergahlarda görülmeye başlanmıştır. Bu döneme kadar şehre özgü dokuyu temsil eden düșük yoğunluklu ve kırsal özellikler taşıyan yapılaşma dokusu korunmuştur. Şekil 2'de bu döneme ilişkin kentsel doku örnekleri sunulmaktadır.

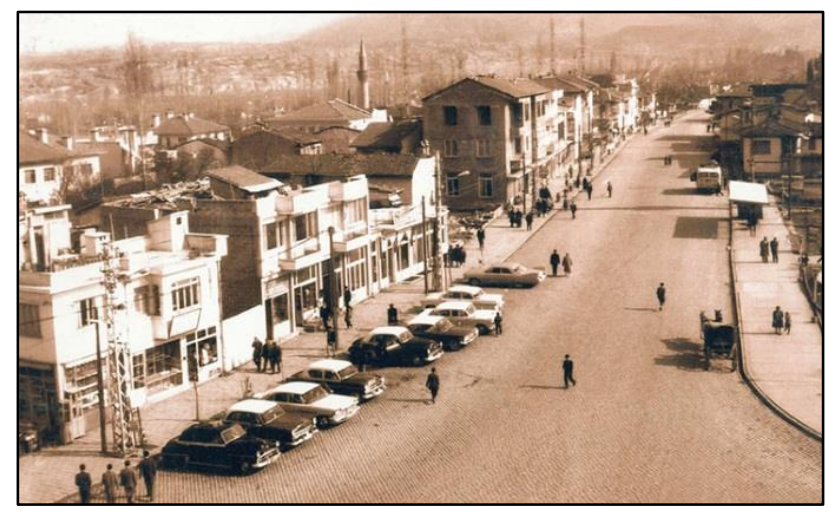

(a)

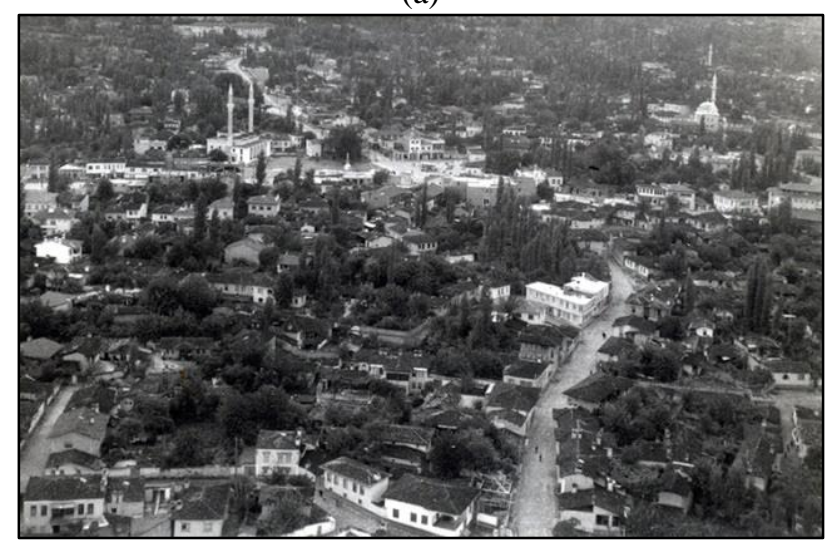

(b)

Şekil 2. 1950 - 1960 döneminde Denizli şehrinin kentsel dokusu [19] (a ve b)

Ancak 1960'lı yıllardan 1980'li yıllara kadar geçen süreçte sanayileşmenin artışı göç olgusunu şehir genelinde tetikleşmiş olup; kent nüfusu artarken kır nüfusu önemli ölçüde azalmıştır. Kırsal nitelikli yerleşmelerin ağırlıklı olduğu şehir nüfusu, yaklaşık 20 yıllık zaman diliminde (1950 - 1970 y1lları) 20.000 kişiden 100.000 kişiye yükselmiştir [13, 15]. Bu süreçte yaşanan göçler sonucunda yoğun konut talebinin karşılanması için mevcut dokuyla benzerlik göstermeyen, apartmanlaşma eğilimin sıç̧a görüldüğü, gecekondulaşmanın başladığı, meydanların ve büyük yapı adalarının kent merkezinde yoğunlaştığı bir yapılaşma düzenine geçilmiştir [12]. 1980 sonrası dönemde ise Türkiye genelinde uygulanan "konut stokunu arttırma politikası" aracılığıyla yapılan uygulamalar sonucunda, Denizli'de ihtiyaç fazlası konut arzı yapıldığı ve bu stokun eritilmesinde Pamukkale Üniversitesi'nin önemli payı olduğu ifade edilmektedir [19].

Mevcut yapılaşma yoğunluğu ve kentsel gelişme eğilimleri incelendiğinde, kent merkezlerinden (Bayramyeri ve Çınar) uzaklaştıkça konut yoğunluğunun azaldığı, şehrin güney ve doğu kısımlarında (Sevindik, Karşıyaka, İlbade) ve üretim tesislerinin bulunduğu bölgelerde alt gelir düzeyine sahip gruplarının yer seçtiği; kapalı sitelerin yoğun olduğu bölgelerin bulunduğu kuzey kesimlerde (Bağbaşı, Yenişehir, Çukur, Karcı, Şirinköy, Servergazi) orta - üst gelir düzeyine sahip grupların yer seçtiği; kentin batısında ve kent merkezine yakın bölgelerde (İstiklal, Yenişehir, Atakent, Pamukkale, Merkezefendi) ise orta gelir grubunun yer seçtiği görülmektedir. Şekil 3'te farklı gelir gruplarının kentsel mekanda yer seçtiği bölgelere ilişkin görseller sunulmuştur.

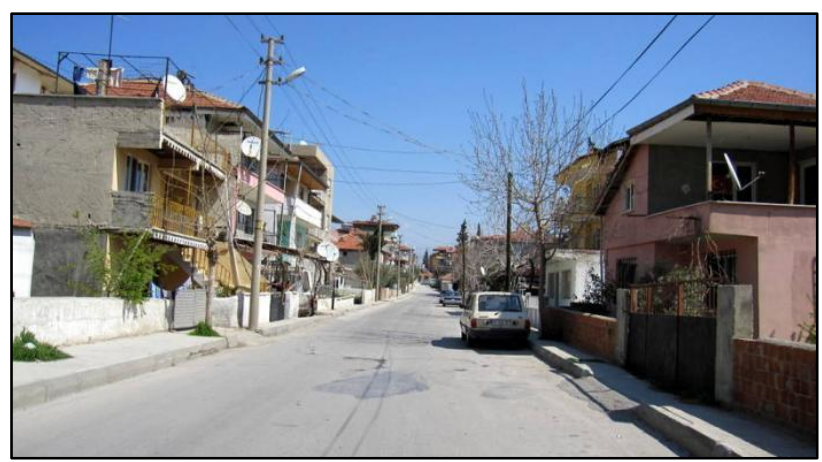

(a)

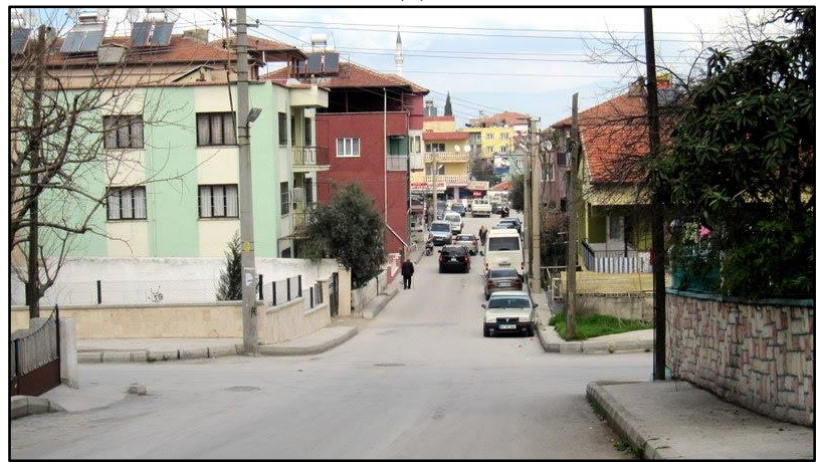

(b) 


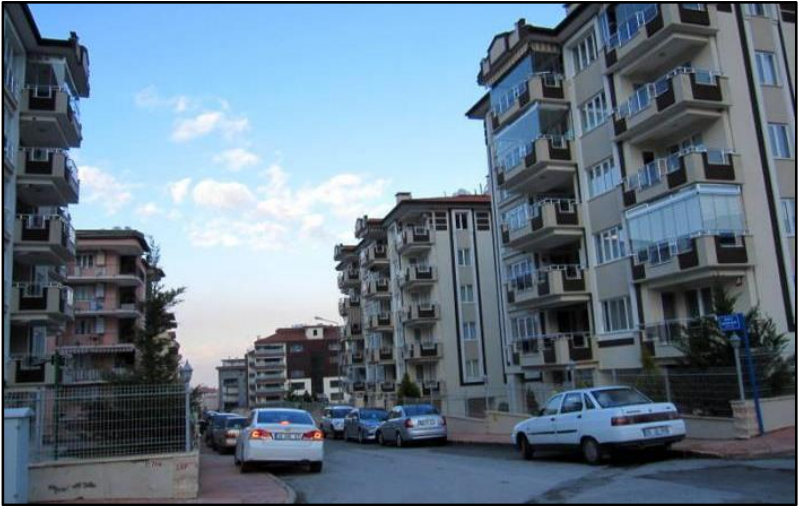

(c)

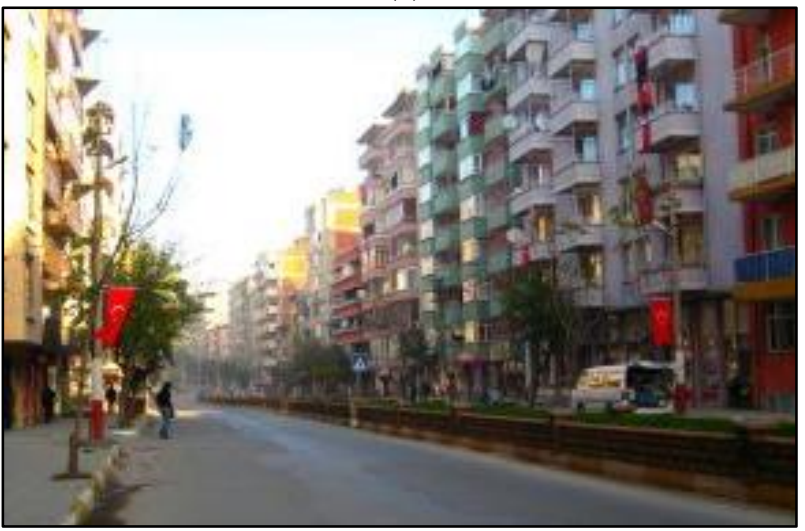

(d)

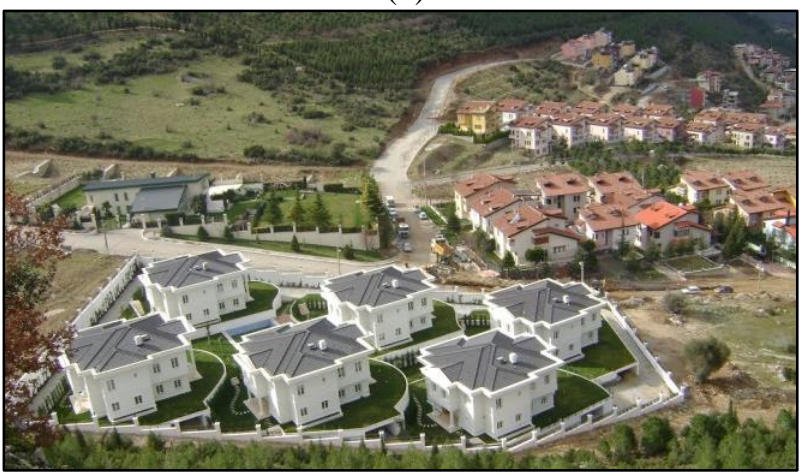

(e)

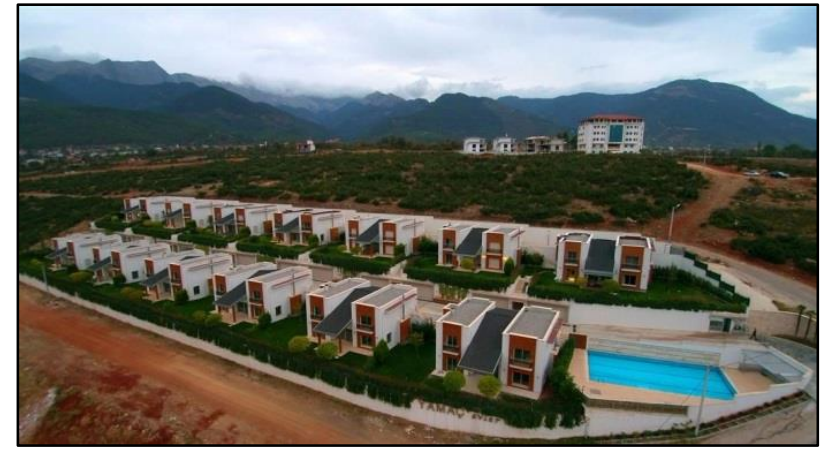

(f)

Şekil 3. Farklı gelir düzeylerinin kent genelindeki yer seçimleri ( $a$ ve b alt gelir grubunun, $c$ ve d orta gelir grubunun, e ve füst gelir grubunun tercih ettiği bölgelerdir)

\section{DENIZLI'DE 6360 SAYILI KANUN SONRASINDAKİ DURUM (SITUATION AFTER THE 6360 LAW IN DENIZLI)}

6360 sayılı kanunla tüzel kişiliği ortadan kaldırılarak "mahalle" statüsüne alınan ve Pamukkale ve Merkezefendi İlçeleri'nde yer alan toplam 25 yerleşim alanı (Pamukkale İlçesi'nde 17 ve Merkezefendi İlçesi'nde 8 olmak üzere, toplamda mahalle statüsüne alınan 25 köy ve belediye) çalışma kapsamında örnek alan olarak seçilmiştir. Kanunun yürürlüğe girmesiyle, toplamda 17 köy ve belediye Denizli Büyükşehir Belediyesi'nin merkez ilçelerinden biri olan Akköy İlçesi sınırlarına dâhil edilmiştir. Akköy ilçesinin ismi sonradan Pamukkale olarak değiştirilmiştir. Günümüzde Pamukkale İlçesi'ne bağlı toplamda 54 mahalle (37 mahalle, 6 belde ve 11 köy) yer almaktadır. Benzer biçimde, diğer merkez ilçelerden biri olan Merkezefendi İlçesi'nin sınırlarına toplamda 8 köy ve belediye dâhil edilmiştir. Mevcut durumda Merkezefendi İlçesi'ne bağlı toplamda 50 mahalle (42 mahalle, 2 belde ve 6 köy) bulunmaktadır [17]. Şekil 4'te çalışma alanı kapsamında yer alan il ve ilçeler ile çalışma alanına ait sınırın gösterilmiştir. Tablo 2'de Pamukkale ve Merkezefendi İlçeleri sınırlarına dahil edilen köy ve belediyeler sunulmakta olup, Tablo 3 'te ise bu ilçelerin sınırlarına dahil edilen mahalleler ve yıllara göre ilçe nüfusları gösterilmiştir.

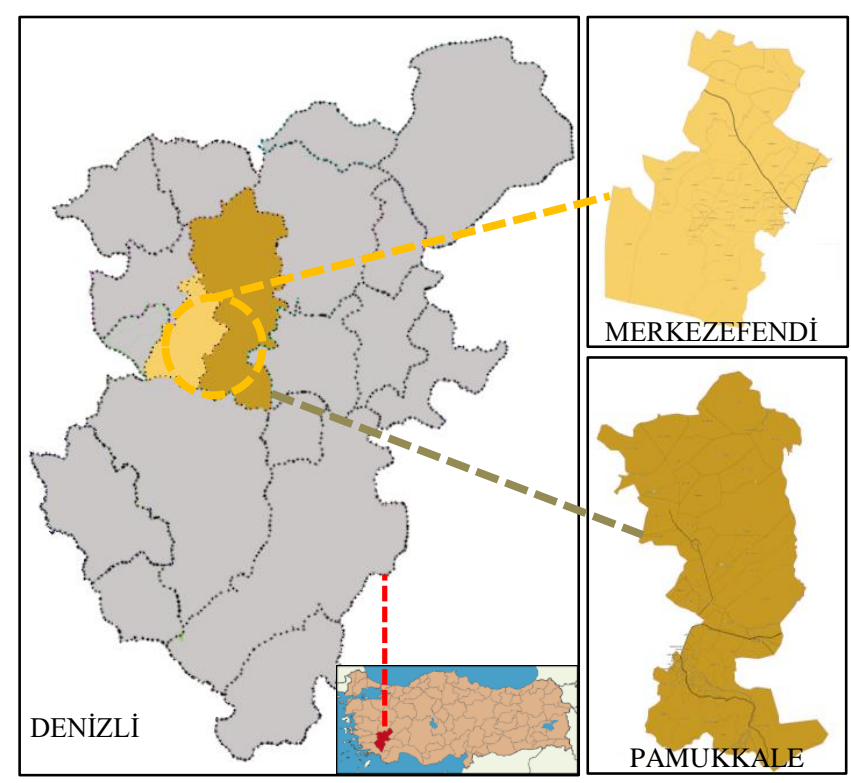

Şekil 4. Çalışma kapsamında yer alan il ve ilçeler ile çalıșma alan sınırı 
Tablo 2. 6360 Sayılı Kanunla Pamukkale ve Merkezefendi İlçeleri'ne Dahil Edilen Köy ve Belediyeler

\begin{tabular}{|c|c|c|c|}
\hline \multicolumn{2}{|c|}{$\begin{array}{c}\text { Pamukkale İlçesi'ne Dahil } \\
\text { Edilen Köy ve Belediyeler }\end{array}$} & \multicolumn{2}{|c|}{$\begin{array}{c}\text { Merkezefendi İlçesi'ne Dahil } \\
\text { Edilen Köy ve Belediyeler }\end{array}$} \\
\hline $\begin{array}{c}\text { Köy / } \\
\text { Belediye }\end{array}$ & $\begin{array}{c}\text { Bağlı } \\
\text { Olduğu } \\
\text { İlçeler }\end{array}$ & $\begin{array}{c}\text { Köy / } \\
\text { Belediye }\end{array}$ & $\begin{array}{c}\text { Bağlı } \\
\text { Olduğu } \\
\text { İlçeler }\end{array}$ \\
\hline $\begin{array}{c}\text { Irlıanlı } \\
\text { Belediyesi }\end{array}$ & Merkez & $\begin{array}{c}\text { Aşağışamlı } \\
\text { Belediyesi }\end{array}$ & Merkez \\
\hline $\begin{array}{c}\text { Gözler } \\
\text { Belediyesi }\end{array}$ & Merkez & $\begin{array}{c}\text { Başkarcı } \\
\text { Belediyesi }\end{array}$ & Merkez \\
\hline $\begin{array}{c}\text { Karahayııt } \\
\text { Belediyesi }\end{array}$ & Merkez & Altındere & Merkez \\
\hline $\begin{array}{c}\text { Pamukkale } \\
\text { Belediyesi }\end{array}$ & Merkez & Çeltikçi & Merkez \\
\hline $\begin{array}{c}\text { Pınarkent } \\
\text { Belediyesi }\end{array}$ & Merkez & Kumkısık & Merkez \\
\hline $\begin{array}{c}\text { Uzunpınar } \\
\text { Belediyesi }\end{array}$ & Merkez & Salihağa & Merkez \\
\hline Akdere & Merkez & Üzerlik & Merkez \\
\hline Develi & Merkez & Yeşilyayla & Merkez \\
\hline Eldenizli & Merkez & - & - \\
\hline Eymir & Merkez & - & - \\
\hline Güzelpınar & Merkez & - & - \\
\hline Haytabey & Merkez & - & - \\
\hline Karataş & Merkez & - & - \\
\hline Kocadere & Merkez & - & - \\
\hline Kurtluca & Merkez & - & - \\
\hline Küçükdere & Merkez & - & - \\
\hline Yeniköy & Merkez & - & - \\
\hline
\end{tabular}

Tablo 3. Pamukkale ve Merkezefendi İlçeleri'nin Kapsadığı Mahalleler ve Yıllara Göre İlçe Nüfusları

\begin{tabular}{|c|c|c|c|c|}
\hline \multirow{2}{*}{ Yll } & \multicolumn{2}{|c|}{$\begin{array}{c}\text { Pamukkale İlçesi } \\
\text { Sınırlarına Dahil Edilen } \\
\text { Mahalleler }\end{array}$} & \multicolumn{2}{|c|}{$\begin{array}{c}\text { Merkezefendi İlçesi } \\
\text { Sinırlarına Dahil Edilen } \\
\text { Mahalleler }\end{array}$} \\
\hline & $\begin{array}{c}\text { İlçe } \\
\text { Nüfusu }\end{array}$ & Mahalleler & $\begin{array}{c}\text { İlçe } \\
\text { Nüfusu }\end{array}$ & Mahalleler \\
\hline 2007 & $\begin{array}{l}5.225 \\
\text { (Akköy) }\end{array}$ & $\begin{array}{c}\text { Akhan, } \\
\text { Aktepe, } \\
\text { Anafartalar, } \\
\text { Asmalievler, }\end{array}$ & 6.587 & $\begin{array}{l}1200 \text { Evler, } \\
\text { Adalet, } \\
\text { Akçeşme, } \\
\text { Akkonak, }\end{array}$ \\
\hline 2008 & $\begin{array}{l}5.609 \\
\text { (Akköy) }\end{array}$ & $\begin{array}{c}\text { Atalar, } \\
\text { Bağbaşı, } \\
\text { Cankurtaran, } \\
\text { Cumhurivet, }\end{array}$ & 6.379 & $\begin{array}{l}\text { Alpaslan, } \\
\text { Altıntop, } \\
\text { Bahçelievle } \\
\text { r, Barbaros, }\end{array}$ \\
\hline 2009 & $\begin{array}{c}5.518 \\
\text { (Akköy) }\end{array}$ & $\begin{array}{l}\text { Çamlaralt1, } \\
\text { Deliktaş, } \\
\text { Dokuzkavakl } \\
\text { ar, Fatih, }\end{array}$ & 8.403 & $\begin{array}{l}\text { Barutçular, } \\
\text { Bereketler, } \\
\text { Bozburun, } \\
\text { Çakmak, }\end{array}$ \\
\hline 2010 & $\begin{array}{l}5.492 \\
\text { (Akköy) }\end{array}$ & $\begin{array}{l}\text { Goncal,, } \\
\text { Gökpınar, } \\
\text { Güzelköy, } \\
\text { Hacıkaplanlar }\end{array}$ & 8.486 & $\begin{array}{l}\text { nü, } \\
\text { Servergazi, } \\
\text { Eskihisar, } \\
\text { Gerzele, }\end{array}$ \\
\hline 2011 & $\begin{array}{l}5.466 \\
\text { (Akköy) }\end{array}$ & $\begin{array}{c}\text {, Hürriyet, } \\
\text { İncilipınar, } \\
\text { İstiklal, Kale, } \\
\text { Karaovar, }\end{array}$ & 8.685 & $\begin{array}{l}\text { Göveçlik, } \\
\text { Gültepe, } \\
\text { Gümüşçay, } \\
\text { Hacıeyüplü }\end{array}$ \\
\hline
\end{tabular}

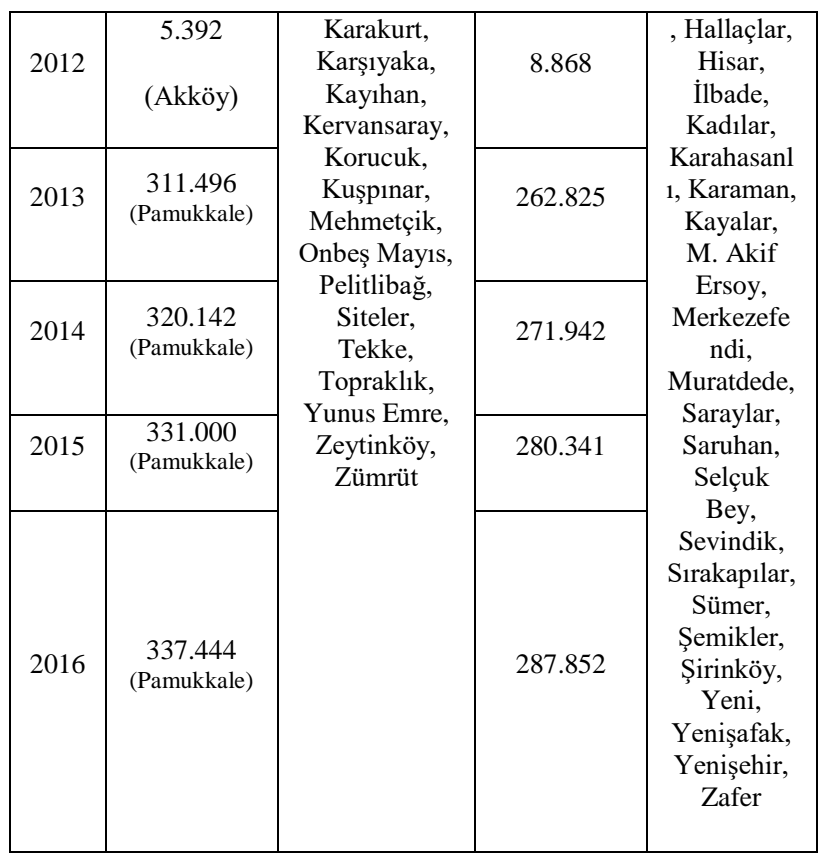

Çalı̧̧ma kapsamında incelenen Pamukkale ve Merkezefendi İlçeleri, ağırlıklı olarak sanayi, tarım ve hayvancılık faaliyetlerinin görüldüğü, tarıma dayalı sanayi uygulamalarının gerçekleştirildiği ve Denizli İli'nin nüfus yoğunluğunun en fazla olduğu merkez ilçeleridir. $\mathrm{Bu}$ yerleşim yerleri hâlihazırda verimli tarım arazileri ve orman alanları bakımından oldukça zengin olmakla birlikte, Denizli'nin gelişme yönlerinde yer alması bakımından da artan konut talebine yönelik mekânsal gelişmenin gözlendiği yerleşimlerdir. Ülke genelinde 1970'li yıllardan sonra yaşanan gecekondulaşma ve kaçak yapılaşma sürecinden etkilenen bu ilçelerde artan konut talebini karşılamak üzere kentsel nitelikli alanlar giderek artmakta ve şehrin arazi kullanım deseni değişmektedir. Deprem riskli taşıyan ve kaçak yapılaşmanın görüldüğü bölgelerde yaklaşık 20 yıllık dönemde önemli kentsel dönüşüm uygulamalarının yapılması ve geleneksel konut dokusuna uygun yerleşim alanlarının planlanması yerel yönetimin gündemini oluşturmaktadır.

2016 yılında Çevre ve Şehircilik Bakanlığı İl Müdürlüğü tarafından yayınlanan Denizli İli 2015 Yılı Çevre Durum Raporu'nda, Denizli genelinde araziler kullanım türlerine göre sinıflandırılmış; buna göre tarım arazilerinin büyüklüğünün 376,738 ha (\%32'lik kısım), çayır - mera alanlarının büyüklügünün 22,157 ha (\%2'lik kısım), orman - fundalık alanlarının büyüklüğ̈̈nün 588.672 ha (\%49'luk kısım) ve tarım dışı yerleşim alanlarının büyüklüğünün 199,233 ha (\%17'lik k1sım) olduğu belirtilmiştir. İlçeler baz alınarak belirlenen tarım alanlarının büyüklüğü incelendiğinde ise, Pamukkale İlçesi'nde toplam 28,836 ha (toplamın yaklaşık \%8'lik kısmı) ve Merkezefendi İlçesi'nde toplam 6,172 ha (toplamın yaklaşık \%8'lik kısmı) tarım alanı olduğu tespit edilmiştir [3]. Şekil 5'te çalışma kapsamında yer alan ilçelere ilişskin 2007 yılına (a), 2009 yılına (b), 2011 y1lına (c), 2013 yllına (d) 2015 yilına (e) ve 2017 yilına (f) ait karşılaştırmalı uydu görüntüleri sunulmaktadır. 


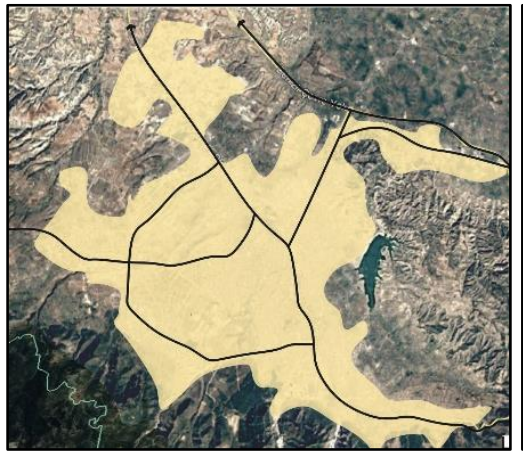

(a)

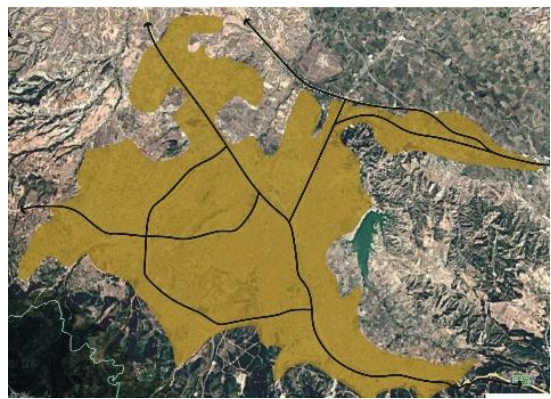

(d)

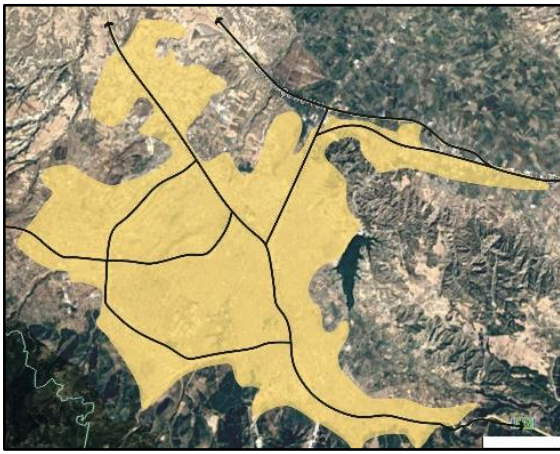

(b)

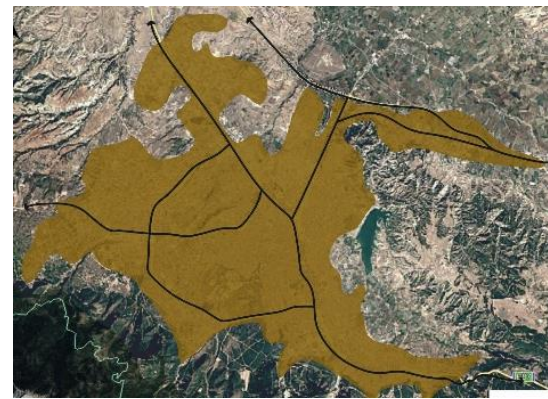

(e)

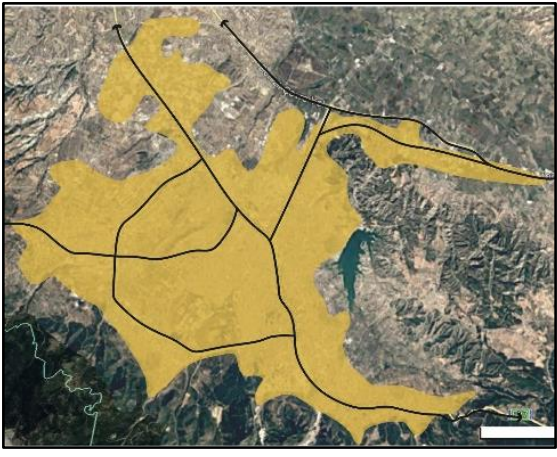

(c)

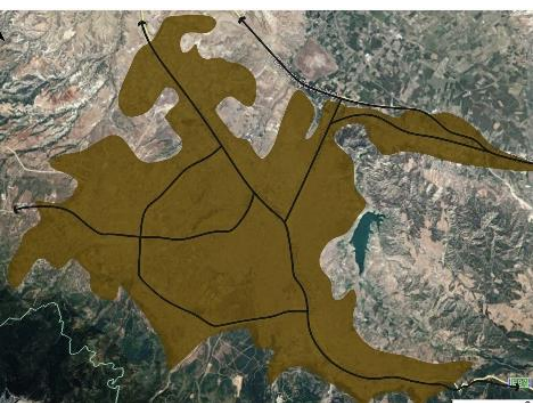

(f)

Şekil 5. 2007 - 2017 yılları arasında çalışma alanına ait karşılaştırmalı uydu görüntüleri [7]

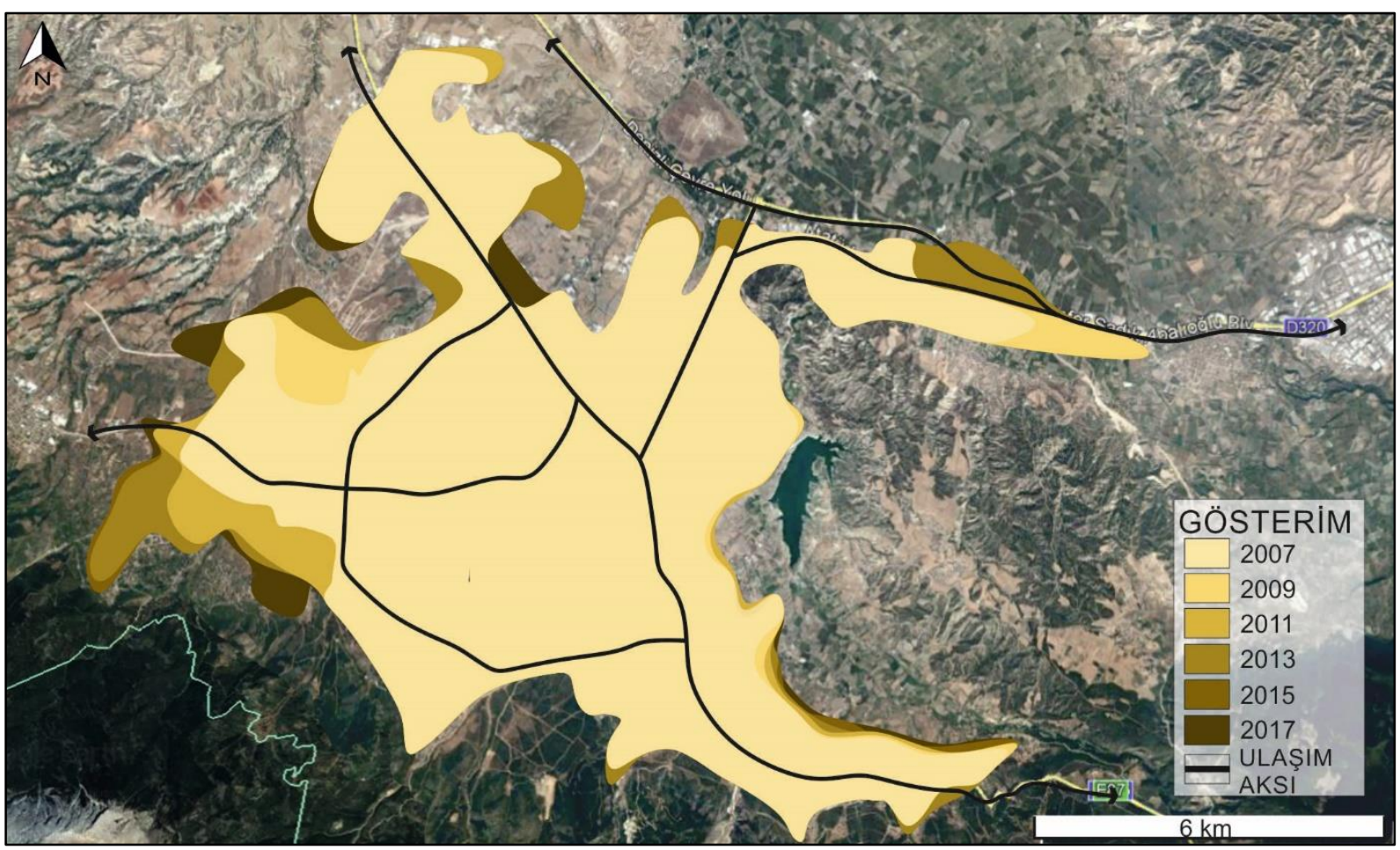

Şekil 6. 2007 - 2017 yılları arasında kentsel mekandaki arazi deseninde meydana gelen değişim ve kentsel yayılmanın yoğunlaştığı bölgeler 
2007 - 2017 yıllarına ait uydu görüntülerinin Google Earth yazılımı kullanılarak elde edilmesi ve çalışma alanı olarak belirlenen alanlardaki mekansal değişimlerin karşılaştırmalı olarak incelenmesi sonucunda, 10 yıllık periyotta bu alanlarda gözlenen değişism ve eğilimlerin kentsel dokuyu ne yönde etkilediği ve kırsal nitelikli alanlarda hangi bölgelerde kayıplar yaşandığı tespit edilmiştir. Çalışma alanında (Pamukkale İlçesi'nin güneyini ve Merkezefendi İlçesi'ni kapsayan alan) yapılan değerlendirmeler sonucunda; çalışma alanında bulunan iki merkez ilçedeki yapılaşma deseni (arazi kullanım deseni) ve kentsel nitelikli alanların genel arazi kullanım türleri içerisindeki oranının 2007 yılından 2017 yılına kadar geçen süreçte önemli ölçüde değiştiği tespit edilmiştir. Yapılaşma deseninin ağırlıklı olarak ana ulaşım aksları ve bu akslar çevresinde konumlanan yerleşim alanları etrafında yayılarak genişlediği saptanmıştır. Buna ek olarak, Denizli bütününde görüldüğü gibi, çalışma alanında kentsel gelişme dinamiklarini yönlendiren en önemli faktörün ana yol aksları olduğu, tarımsal üretim ve hayvancılıkta aktif olarak kullanılabilecek kırsal nitelikli alanların önce işlevinin yitirilmesi ve sonrasında yapılaşmaya açılması yıllar içerisinde izlenebilen bir diğer sonuçtur. Farklı dönemlerde idari sınırlarda meydana gelen değişimler, Denizli'de pek çok belediyenin üst ölçek planlardan bağımsız biçimde plan kararlarını geliştirmesi ve ölçekler arası kademelenmenin sağlanamaması gibi nedenlere bağlı olarak, çalışma alanında kentsel yayılma ve saçaklanma görülmektedir (Şekil 5).

2007 y1lında yerleşim lekesinin şehir merkezinden ana yol güzergahları (Menderes Bulvarı, 29 Ekim Bulvarı ve Ankara Bulvarı (Ankara Yolu) aksları) boyunca doğu, batı ve güneydoğu yönlerinde üzerinde yayılım gösterirken; 2009 y1lında alanın batısına (Adalet, Selçukbey, Karahasanlı ve Yeni Saltık mahallelerinin bulunduğu bölge) ve doğusuna (Akhan ve Güzelköy mahallelerinin bulunduğu bölge) doğru ilerlediğ görülmektedir. 2011 y1lında arazi deseninde önemli farklılıklar ve leke düzeyinde ayrışma yaratacak bir yapılaşma gözlenmezken; 2013 yılında Denizli ile komşu illerin karayolunu bağlantısını sağlayan kuzeyde Denizli Aydın Yolu ve doğuda D-320 Denizli Çevre Yolu güzergahında kentsel alanların önemli yayılmalar gösterdiği tespit edilmiştir. 2015 yılından 2017 yılna kadar geçen sürede ise ağırlıklı olarak çalışma alanının batısında yer alan ve kırsal nitelik taşıyan alanlarda ciddi oranda yapılaşma gözlenmiştir (Şekil 6).

Görmüş ve Cengiz (2016) tarafindan yapılan çalışmada, 2001 - 2013 yılları arasında Merkezefendi ve Pamukkale ilçelerinde kentsel mekanda gerçekleşen değişim ve dönüşümler sonucunda kırsal nitelik taşıyan yaklaşık 50 $\mathrm{km}^{2}$ 'lik alanın yok olduğu, buna karşın kentsel nitelik taşıyan alanlarda yaklaşık $41 \mathrm{~km}^{2}$ 'lik alan artışı olduğu saptanmıştır. Belirtilen yıllar arasında kişi başına düşen kentsel alan artışının 118,4 $\mathrm{m}^{2}$ olduğu, kentsel gelişim yönlerinin şehir merkezinden ana yol güzergahları boyunca doğu, bat1, kuzeybatı ve güneydoğu yönlerinde olduğu sonucunu ortaya koyan çalışmada, kentsel gelişmenin ağırlıklı olarak \%0-10 arasında hafif eğimli alanlarda görüldüğü ifade edilmektedir [21]. Şehrin üç ana ulaşım bağlantısı (Ankara, İzmir ve Antalya yolu) çevresinde kentsel yayılma ve saçaklanmaların görüldüğünün saptandığı çalışmada, yapılan analizler sonucunda yaklaşık 30 y1llık dönem içerisinde gecekondulaşmanın yoğun olduğu mahallelerde tarım alanı kaybı toplam 510 ha, üniversite alanı ve çevresinde tarım alanı kaybı toplam 94 ha, sanayi alanı ve çevresinde meydana gelen tarım alanı kaybı toplam 1704 ha, ana ulaşım güzergahları çevresinde meydana gelen tarım alanı kayb1 toplam 2207 ha, turizm alanları ve çevresinde meydana gelen tarım alanı kaybı toplam 314 ha olarak ölçülmüşür. Kırsal nitelikli alanlarda meydana gelen kaybın en fazla ana ulaşım bağlantıları ve sanayi alanları çevresinde olduğu görülmüştür. Görmüş ve Cengiz tarafından yapılan, kentsel büyümeyi yönlendiren değişkenleri analiz etmeyi amaçlayan ampirik çalışmanın sonuçları ile kırsal nitelikli alanlarda görülen yapılaşma baskısını vurgulamayı amaçlayan bu çalışmanın sonuçlarının önemli ölçüde tutarlılık gösterdiği saptanmıştır.

\section{SONUC (CONCLUSSION)}

6360 sayılı kanunun yürürlüğe girmesiyle kentsel mekanda farklı nitelikteki yerleşmelerin oluşturduğu mekan organizasyonunda meydana gelen değişsimleri, eğilimleri ve kazançlar / kayıpları doğru bir biçimde yorumlayabilmek için, kanun öncesi ve sonrası dönemin karşılaştırmalı olarak incelenmesi ve ortaya çıkan etkilerin izlenmesi oldukça önemlidir. Bu çalışma, böyle bir noktadan hereketle, 2007 - 2017 yılları arasındaki dönemde bir büyükşehir olan Denizli'nin iki merkez ilçesi özelinde (Pamukkale ve Merkezefendi İlçeleri) yerel nitelikleri (arazi kullanım türleri, eğilimler, vb.) gözönünde bulundurarak bir araştırma yapmayı ve bulgular üzerinden bir tartışma yürütmeyi amaçlamıştır. Farklı yıllara ait uydu görüntüleri kullanılarak ortaya konulan mekansal değişimlere ilişsin yapılan değerlendirmelerin, kentsel ve mekânsal gelişme dinamiklerinin ve eğilimlerinin yönetilmesinde belirleyici olan yerel düzeydeki yönetimsel yapılanmaya ait yetki ve sorumluklarının nasıl ve hangi amaçla kullanıldı̆̆ını, özellikle tarımsal alanlar üzerindeki mekânsal etkilerini ortaya koyması bakımından oldukça önemli olduğu düşünülmektedir.

Yapılan değerlendirmeler kısaca özetlenecek olursa: (1) Üst ölçek planlarla eşgüdümlü olmayan plan kararlarının her yerel yönetim tarafindan üretilmesi ve ölçekler arası kademelenmenin sağlanamaması gibi nedenlerden dolayı çalışma alanında kentsel yayılma ve saçaklanma görülmektedir. (2) Denizli'de kentsel yayılma ve saçaklanmaya neden olan ve planlama disiplini içerisinde tartışılan çeşitli faktörler (mekansal, toplumsal, sosyal, ekonomik faktörler, vb.) kırsal nitelik taşıyan alanları (tarım alanları, çayırlar, meralar, ormanlar, vb.) olumsuz yönde etkilemektedir. (3) Kentsel gelişim ve büyüme eğilimlerinin genellikle ana yol güzergahları boyunca doğu, bat1, kuzeybat1 ve güneydoğu yönlerinde olduğu ve 
yeni yerleşim birimlerinin ağırlıklı olarak \%0-10 arasında hafif eğimli alanlarda yer seçtiği görülmektedir. (4) Kırsal nitelikli alanlarda meydana gelen kaybın en fazla olduğu alanlar, ana ulaşım bağlantılarının ve sanayi alanlarının çevresinde bulunan alanlardır.

6360 sayılı kanunun yürürlüğe girmesi sonucunda, Denizli şehrinin metropoliten etki alanı içerisinde ve çevresinde yer alan kırsal nitelik taşıyan yerleşimlerin, kırsal yaşam tarzının sürdürülebilmesi ve yerel niteliklerinin ön plana çıkarılacak kırsal kalkınmanın sağlanması gibi temel konularda yeni sorunlarla yüzleşmek zorunda kalınacağı açıktır. $\mathrm{Bu}$ sorunlar ekonomik, sosyal ve mekansal boyutlarıyla hem kırsal alanlarda yaşama kültürüne sahip halk, hem nüfusun hızla arttığ 1 kentsel alandarda artan konut talebinin karşılandığ kimliksiz yerleşim birimlerinde ikamet etmekte olan kentliler, hem de bu yerleşimlerin yetki ve sorumluluk sahasına alındığ 1 yerel yönetimler için giderek daha görünür hale gelecektir.

Tarım alanlarının önemli ölçüde kaybedildiği plansız ve kontrolsüz yapılaşma koşullarında, 6360 sayılı kanunun yürürlüğe girmesiyle yetki ve sorumluluk alanı genişleyen tüm yerel yönetimlerin yeterli teknik altyapı hizmetlerinin adil biçimde tüm yerleşim birimlerine ulaştırılması, teknik ve mali açıdan yeterli imkanlara sahip olmayan belediyelerin denetlenmesi ve desteklenmesi, yapılaşmanın denetlenmesi ve kır - kent ikileminin mekansal ve toplumsal boyutlarıyla doğuracağı olumsuz sonuçları tartışmak ve bunlara çözüm önerileri geliştirmek eskiye göre daha önemli bir hale gelmiştir. Bu süreçte yerelleşme, demokratikleşme, yerinden yönetim ve bütünleşik alan modellerinin geliştirilmesi ön planda tutulması gereken konular arasında yerini almıştır.

\section{KAYNAKLAR (REFERENCES)}

[1] M. Ayyıldız, A. Çiçek, B. Ayyıldız. Nevşehir Bilim ve Teknoloji Dergisi (TARGID), Özel Sayı, 280-285, 2016.

[2] H. Çelikyay. Değişen Kent Yönetimi ve 6360 Say1lı Büyükş̧ehir Yasası. SETA Dergisi, s.101, 2014.

[3] Çevre ve Şehircilik Bakanlığı Denizli İl Müdürlüğü (ÇŞB). Denizli İli 2015 Yılı Çevre Durum Raporu. ÇED ve Çevre İzinleri Şube Müdürlüğü, Denizli Valiliği, Çevre ve Şehircilik Bakanlığı Denizli İl Müdürlügü, Denizli, 2016.

[4] E. Dik. 6360 Sayılı Kanun Bağlamında Köylerin Mahalleye Çevrilmesi Sorunu. Mülkiye Dergisi, 38 (1), $75-102,2014$

[5] E.M. Ercan. Kentlerimizin İçinde Bulunduğu Planlama ve Yönetim Sorunları. Planlama, 2007/2, 2007.

[6] M. Ersoy. 6360 Sayılı Yasa ve Mekânsal Planlama Sorunları. GAP Belediyeler Birliği Dergisi, Mayıs, Haziran Temmuz sayıs1, 20-32, 2013.

[7] Google Earth. 2007 - 2017 yılları arası uydu görüntüleri, 2017.

[8] M.A. Gökaçtı. Dünyada ve Türkiye'de Belediyecilik. Ozan Yayıncılık, İstanbul, 1996.
[9] F. Gökyurt, A. Kındap, V.İ. Sarı. Türkiye için yeni bir şehir tanımı gerekli mi?. Çağdaş Yerel Yönetimler Dergisi, 24 (1),1-32, 2015.

[10] K. Göymen. Türk Belediyeciliğinde Ankara Örneği: 1973-1980. Türk Belediyeciliğinde 60. Y11, Uluslararas1 Sempozyum, Ankara, 23-24 Kasım 1990, Bildiriler ve Tartışmalar, Ankara Büyükşsehir Belediyesi Yayınları, Ankara, ss. 395-404, 1990

[11] İ. İrdem, A. Mutlu. 6360 Sayılı Yasayla "Kir-Kent" Kavramlarının Muğlâklașması Sorunu ve Olası Sonuçları. KAYSEM 10, İzmir, 159-176, 2016.

[12] B. Küçük. Yapı-Çevre Etkileri ve Denizli'de Eski Hayat. HABITTAT II Kent Zirvesi, İstanbul 1996 Uluslararas1 Bilimsel Toplantılar, İstanbul Büyükşehir Belediyesi Kültür İșleri Daire Başkanlığı Yayınları, No: 44, ss. 263 271, 1996

[13] A. Marım. Denizli'nin Kentsel Gelișimi ve Planları. Sözlü görüşme notları, Delikliçınar, Denizli, 2009

[14] Şehir Plancıları Odası (ŞPO). Büyükşehir Belediyesi Kanunu Değișikliği Değerlendirme Raporu. TMMOB Şehir Plancıları Odası, Ankara, 2012.

[15] İ. Şenel. Denizli’nin Mimari Gelişimi. Sözlü görüşme notları, Mimarlar Odası, Denizli, 2009.

[16] M. Tezcan. Sosyolojik Yönden Köy. Amme İdaresi Dergisi, 3 (3), 1970.

[17] Türkiye Belediyeler Birliği (TBB). 6360 Sayılı On Dört İlde Büyükşsehir Belediyesi ve Yirmi Yedi İlçe Kurulması İle Bazı Kanun ve Kanun Hükmünde Kararnamelerde Değișiklik Yapılmasına Dair Kanuna İlişkin Rehber, 13, 2014

[18] G.K. Ürkmez, H.Z. Çelik. 6360 Sayılı Yasayla Mekansal İliși Sisteminin Kir-Kent İkileminde Yeniden Yapılanışı ve Yerel Yönetimler: Kayseri İli Örneği. Çağdaș Yerel Yönetimler, 25 (3), 69-94, 2016.

[19] P.S. Yavuzçehre. Denizli Kentsel Mekanında Değişim. İdealkent Kent Araştırmaları Dergisi, 2017.

[20] N.S. Özcan. Denizli Kentinin Kaçınılmaz Sorunu: Kentsel Hava Kirliliği, PERSPEKTIFFLER - 2017 Denizli Dosyası, Pamukkale Üniversitesi Yayınları, 1. Bask1, Denizli, 2017.

[21] S. Görmüş, S. Cengiz. Denizli'de Kentsel Büyümeyi Yönlendiren Değişkenlerin Analizi, 6. Uzaktan Algilama-CBS Sempozyumu (UZAL-CBS2016), Adana, 2016. 